\title{
PENGARUH FINANCIAL DISTRESS (ALTMAN Z-SCORE) TERHADAP RETURN SAHAM PADA PERUSAHAAN SEKTOR ANEKA INDUSTRI YANG TERDAFTAR DI BURSA EFEK INDONESIA
}

\author{
Oleh: \\ Debby Julini \\ S1 Akuntansi \\ Yansen Siahaan, Mahaitin Sinaga, Rosanna Purba
}

Abstraksi

Penelitian ini bertujuan untuk mengetahui gambaran financial distress (Altman Z-Score) dan return saham serta untuk mengetahui pengaruh financial distress terhadap return saham pada Perusahaan Sektor Aneka Industri yang terdaftar di Bursa Efek Indonesia untuk periode 2009 sampai dengan periode 2013. Penelitian ini menggunakan desain penelitian kepustakaan dengan sumber data yang digunakan adalah data sekunder berupa laporan keuangan dan harga saham Perusahaan Sektor Aneka Industri yang terdaftar di Bursa Efek Indonesia. Data tersebut diolah dengan menggunakan teknik analisis data yaitu analisis Altman Z-Score

Data z-score yang telah diketahui tersebut kemudian dianalisis dengan menggunakan analisis deskriptif yaitu terdiri dari analisis deskriptif kualitatif dan kuantitatif. Dalam penelitian ini digunakan instrumen penclitian berupa statistik deskriptif, analisis regresi linier sederhana dan uji hipotesis. Hasil penelitian ini menunjukkan bahwa financial distress (Altman Z-Score) berpengaruh positif dan tidak signifikan terhadap return saham. Hal tersebut berdasarkan hasil analisis regresi linier sederhana yaitu ArtanRt $=0,124+0,109 \operatorname{ArtanFd}+\varepsilon$ yang menunjukkan bahwa financial distress berpengaruh positif terhadap return saham. Dari hasil uji t diperoleh hasil bahwa $\mathrm{t}_{\text {hitung }}<\mathrm{t}_{\text {tabel }}$ atau 1,310 $<1,97730$ sedangkan tingkat signifikansi yang diperoleh adalah $0,193>0,05$ yang menunjukkan bahwa financial distress berpengaruh tidak signifikan terhadap return saham.

Kata kunci: Financial Distress, Altman Z-Score, Return Saham

Abstraction

This study aims to find out the description of financial distress and stock return and to find out the influence of financial distress on stock return at company miscellaneous industry sector which listed on Indonesia Stock Exchange for the period 2009 to 2013. This study used a design research literature with the source data used are secondary data from financial reports and stock prices of the company miscellaneous industry sector listed on Indonesia Stock Exchange. The data is processed using a data analysis technique which analyzes the Altman Z-Score

Z-Score data that has been known is then analyzed using descriptive analysis consisted of descriptive analysis of qualitative and quantitative. This study used research instruments in the form of descriptive statistics, simple linear regression analysis, classic assumption test and test hypotheses. The result of this study showed that financial distress (Altman Z-Score) has the positive influences and not significant on stock returns. It is based on the results of the simple linear regression analysis ArtanRt $=0,124+0,109$ ArtanFd $+\varepsilon$ which showed that the financial distress positive effect on stock return. From the results of the t test result that $t_{\text {test }}<t_{\text {table }}$ or $1,310<$ 1,97730 whereas the significance level obtained is 0,193>0,05 which showed that the financial distress insignificant effect on stock returns.

\section{Keywords : Financial Distress, Altman Z-Score, Stock Return}

\section{A. PENDAhuluan}

\section{Latar Belakang Masalah}

Sebelum mengalami kebangkrutan pada umumnya perusahaan terlebih dahulu mengalami kesulitan keuangan atau lebih dikenal dengan sebutan financial distress. Menurut Zahara (2013:26), financial distress merupakan kondisi dimana keuangan perusahaan dalam keadaan tidak sehat atau krisis. Kondisi ini diawali dengan kesulitan likuiditas yaitu perusahaan kesulitan memenuhi kewajibannya kepada perbankan. Financial distress terjadi sebelum kebangkrutan. Kebangkrutan sendiri biasanya diartikan sebagai suatu keadaan atau situasi dimana perusahaan gagal atau tidak mampu lagi memenuhi kewajiban- kewajiban debitur karena perusahaan mengalami kekurangan dan ketidakcukupan dana untuk menjalankan usahanya sehingga tujuan ekonomi yang ingin dicapai oleh perusahaan tidak terpenuhi.

Salah satu metode yang dapat digunakan untuk memprediksi adanya financial distress pada suatu perusahaan adalah dengan menggunakan metode Altman Z-Score yang dibuat oleh Dr. Edward I. Altman pada tahun 1968. Metode ini menggunakan rasio-rasio tertentu dalam rangka memprediksi risiko financial distress sebuah perusahaan. Menurut Ardiyos (2010:1021) dalam kamus besar akuntansi, Z-Score adalah skor yang diberikan pada tiap-tiap variabel yang di analisis. Skor yang diberikan Altman diklasifikasikan ke 
dalam tiga kelompok yaitu jika nilai $\mathrm{Z}<1,8$ maka termasuk perusahaan yang bangkrut, jika nilai $1,8<$ $\mathrm{Z}<2,99$ maka termasuk grey area dan jika nilai $\mathrm{Z}>$ 2,99 maka termasuk perusahaan yang tidak bangkrut.

Kesalahan prediksi terhadap kelangsungan operasi suatu perusahaan di masa yang akan datang dapat berakibat fatal yaitu dapat mengakibatkan perusahaan kehilangan pendapatan atau investasi yang telah ditanamkan oleh investor pada suatu perusahaan. Oleh karena itu, pentingnya suatu model prediksi kebangkrutan suatu perusahaan menjadi hal yang sangat dibutuhkan oleh berbagai pihak seperti pemberi pinjaman (kreditor), investor, pemerintah, akuntan, dan manajemen.

\section{Rumusan Masalah}

a. Bagaimana gambaran financial distress (Altman Z-Score) dan return saham pada Perusahaan Sektor Aneka Industri yang terdaftar di Bursa Efek Indonesia?

b. Apakah financial distress (Altman Z-Score) berpengaruh terhadap return saham pada Perusahaan Sektor Aneka Industri yang terdaftar di Bursa Efek Indonesia?

\section{Tujuan Penelitian}

a. Untuk mengetahui gambaran financial distress (Altman Z-Score) dan return saham pada Perusahaan Sektor Aneka Industri yang terdaftar di Bursa Efek Indonesia.

b. Untuk mengetahui apakah financial distress (Altman Z-Score) berpengaruh terhadap return saham pada Perusahaan Sektor Aneka Industri yang terdaftar di Bursa Efek Indonesia.

\section{Metode Penelitian}

Jumlah objek penelitian yang digunakan adalah sebanyak 28 perusahaan dari Sektor Aneka Industri yang terdaftar di Bursa Efek Indonesia yang telah memenuhi kriteria penarikan objek penelitian. Sumber data yang digunakan oleh penulis dalam penelitian ini adalah data sekunder yaitu berupa laporan keuangan dan harga saham perusahaan yang diperoleh dari website www.idx.co.id dan http://www.duniainvestasi.com/ serta sumber lainnya. Teknik pengumpulan data yang digunakan adalah metode dokumentasi.

Data dianalisis dengan analisis Altman ZScore yang terdiri dari lima komponen yaitu $\mathrm{X}_{1}$ (working capital/total asset), $\mathrm{X}_{2}$ (retained earning /total asset) $\mathrm{X}_{3}$ (earning before interest and tax/total asset), $\mathrm{X}_{4}$ (MVE/book value of total debt), $\mathrm{X}_{5}$ (sales/total asset)

\section{B. LANDASAN TEORI}

\section{Laporan Keuangan}

Menurut Baridwan (2004:17), definisi laporan keuangan merupakan suatu ringkasan dari pencatatan transaksi keuangan yang terjadi selama tahun buku yang bersangkutan. Sedangkan menurut Brigham dan Joel (2006:45), laporan keuangan tahunan adalah sebuah laporan yang diterbitkan oleh perusahaan untuk para pemegang sahamnya.
Menurut Syahyunan (2004:24), ada 3 jenis laporan keuangan dasar yang biasa digunakan untuk menggambarkan kondisi keuangan perusahaan yaitu: a. Neraca

b. Laporan laba rugi, pemasaran dan administrasi.

c. Laporan arus kas

Tujuan khusus dari laporan keuangan adalah menyajikan laporan keuangan secara wajar dan sesuai dengan prinsip-prinsip akuntansi yang berlaku umum, posisi keuangan, hasil operasi, dan perubahan-perubahan lainnya dalam posisi keuangan. Tujuan kualitatif dari laporan keuangan adalah:

a. Relevansi,

b. Dapat dimengerti,

c. Dapat diverifikasi

d. Netralitas

e. Ketepatan waktu

f. Komparabilitas (daya banding)

g. Kelengkapan

Rasio keuangan digunakan sebagai salah satu alat dalam menganalisis segala sesuatu yang menyangkut penggunaan informasi akuntansi untuk mengetahui posisi keuangan agar dapat dilihat bagaimana kondisi keuangan perusahaan apakah dalam keadaan sehat atau mengalami financial distress. Menurut Martono dan Harjito (2002:55), pada dasarnya rasio keuangan diklasifikasikan menjadi empat antara lain :

a. Rasio Likuiditas

b. Rasio Aktivitas

c. Rasio Solvabilitas (Leverage)

d. Rasio Profitabilitas

\section{Financial Distress}

Menurut Atmaja (2003:258), financial distress adalah kondisi dimana perusahaan mengalami kesulitan keuangan dan terancam bangkrut. Jika perusahaan mengalami kebangkrutan maka akan timbul biaya kebangkrutan (bankcruptcy cost) yang disebabkan oleh keterpaksaan menjual aktiva di bawah harga pasar, biaya likuidasi perusahaan, rusaknya aktiva tetap dimakan waktu sebelum terjual dan sebagainya. Bankcruptcy cost ini termasuk direct cost of financial distress. Selain itu ancaman akan terjadinya financial distress juga merupakan biaya, hal tersebut dikarenakan manajemen cenderung akan menghabiskan banyak waktu untuk menghindari kebangkrutan dari pada membuat keputusan yang baik bagi perusahaan. Hal ini termasuk indirect cost of financial distress.

Agar terhindar dari indikasi financial distress, yang menjadi salah satu tanggung jawab perusahaan adalah menghasilkan kinerja perusahaan yang baik. Kemampuan perusahaan dalam memprediksi indikator financial distress yang telah disebutkan sebelumnya dapat mencerminkan bagaimana kinerja perusahaan tersebut.

Altman menemukan lima jenis rasio keuangan yang dapat dikombinasikan untuk melihat perbedaan antara perusahaan yang bangkrut dan yang tidak bangkrut. Persamaan kebangkrutan yang 
ditujukan untuk memprediksi sebuah perusahaan publik manufaktur. Persamaan dari model Altman pertama yaitu :

$Z=1,2 X_{1}+1,4 X_{2}+3,3 X_{3}+0,6 X_{4}+0,999 X_{5}$

Keterangan:

$\mathrm{Z} \quad$ : Z-Score (bankruptcy index)

$\mathrm{X}_{1}$ : working capital/total asset (modal kerja/total aset)

$\mathrm{X}_{2}$ : retained earning /total asset (laba ditahan/total aset)

$\mathrm{X}_{3}$ : earning before interest and tax/total asset (laba sebelum bunga dan pajak/total aset)

$\mathrm{X}_{4}$ : market value of equity/book value of total debt (harga pasar saham dibursa/nilai total utang)

$\mathrm{X}_{5} \quad$ : sales/total asset (penjualan/total aset)

Nilai $\mathrm{Z}$ adalah indeks keseluruhan fungsi multiple discriminant analysis. Menurut The Journal of Finance Altman tahun 1968 dalam Nugroho (2012:4), terdapat angka-angka cut off nilai z yang dapat menjelaskan apakah perusahaan akan mengalami kegagalan atau tidak pada masa mendatang dan ia membaginya ke dalam tiga kategori, yaitu:

a. Jika nilai $\mathrm{Z}<1,8$ maka termasuk perusahaan yang bangkrut.

b. Jika nilai $1,8<\mathrm{Z}<2,99$ maka termasuk grey area (tidak dapat ditentukan apakah perusahaan sehat ataupun mengalami kebangkrutan).

c. Jika nilai $\mathrm{Z}>2,99$ maka termasuk perusahaan yang tidak bangkrut.

\section{Return Saham}

Menurut Baridwan (2004:389), saham merupakan bukti setoran yang dikeluarkan oleh perusahaan sebagai tanda bukti pemilikan yang diserahkan kepada pihak-pihak yang menyetor modal. Saham menurut Situmorang (2008:45), adalah tanda penyertaan modal pada suatu perusahaan perseroan terbatas. Sedangkan menurut Halim (2007:1), kepemilikan di dalam perusahaan dibuktikan dengan lembar saham biasa, setiap lembar saham menyatakan bahwa pemiliknya memiliki $1 / n$ dari saham perusahaan, dimana " $n$ " menunjukkan jumlah lembar saham yang dikeluarkan.

Menurut Brigham dan Joel (2012:8), hal yang menjadi penentuan kekayaan pemegang saham adalah harga saham. Harga saham didasarkan pada arus kas yang diharapkan pada tahun-tahun mendatang, bukan hanya ditahun berjalan. Jadi maksimalisasi harga saham meminta kita untuk melihat operasi secara jangka panjang. Sedangkan menurut Paul Corner's dalam Lubis (2008:121), bahwa harga saham merupakan satu seri fluktuasi batasan (contraint) yang bergerak secara random disekitar nilai intrinsiknya (nilai sebenarnya).

Menurut Hanafi dan Halim dalam Fakhrurozie (2007:14), return sebagai perubahan nilai antara periode $t+1$ dengan periode $t$ ditambah pendapat-pendapat lain yang terjadi selama periode tersebut. Sementara menurut Hartono (2013:235), return merupakan hasil yang diperoleh dari investasi.
Return total merupakan return keseluruhan dari suatu investasi dalam suatu periode yang tertentu, return total sering disebut dengan return saja. Return dapat berupa return realisasian yang sudah terjadi atau return ekspektasian yang belum terjadi tetapi yang diharapkan akan terjadi di masa mendatang.

Menurut Hartono (2013:237), untuk menghitung return total digunakan rumus :

$\mathrm{Rt}=\underline{\mathrm{Pt}-\mathrm{Pt}_{-}}$

$$
\mathrm{Pt}_{-1}
$$

dengan keterangan bahwa Rt adalah return saham, $\mathrm{Pt}$ merupakan investasi periode sekarang dan $\mathrm{Pt}_{-1}$ merupakan investasi periode sebelumnya.

\section{Pengaruh Financial Distress Terhadap Return Saham}

Menurut Sunariyah dalam Fakhrurozie (2007:27), tinggi rendahnya harga saham yang terbentuk di bursa efek lebih banyak dipengaruhi oleh pertimbangan pembeli dan penjual yang melakukan transaksi, pertimbangan ini mencakup kondisi kinerja perusahaan (bangkrut atau sehat), prospek industri, situasi politik, kebijakan pemerintah dan kondisi bursa itu sendiri. Berdasarkan beberapa faktor tersebut, pembeli dan penjual akan membangun pemikiran masing-masing. Didasari pemikiran tersebut maka akan terjadi proses permintaan dan penawaran terhadap saham, berdasarkan hal tersebut harga saham akan terbentuk di bursa. Nilai investasi pada surat berharga dipengaruhi oleh harapan pemodal atau investor tentang kinerja perusahaan sehat atau tidak sehat di masa datang, sebab bagi investor membeli saham berarti membeli prospek perusahaan. Harga saham akan meningkat jika kinerja perusahaan baik dan tidak mengalami financial distress maupun insolvabilitas. Dengan harga saham yang meningkat tersebut berarti akan meningkatkan kemakmuran pemegang sahamnya (Handono, 2007:27).

Banyak faktor yang dapat mempengaruhi harga pasar saham sehingga upaya untuk mengindentifikasi reaksi yang mungkin timbul atas suatu keputusan keuangan menjadi relatif sulit. Faktor lain seperti perubahan kondisi ekonomi, politik, keamanan dan lainnya tentu juga akan mempengaruhi harga pasar saham, namun yang menjadi fokus utama adalah bagaimana pengaruh keputusan keuangan yang dibuat terhadap harga pasar saham jika kondisi lainnya diasumsikan tetap. Harga saham juga dapat dipengaruhi oleh kemampuan manajemen perusahaan untuk beroperasi secara menguntungkan di tengah-tengah lingkungan usaha yang semakin kompetitif. Menurut Syahrir dalam Fakhrurozie (2007:28), dengan kinerja keuangan yang yang menggunakan pengukuran rasio keuangan baik Altman Z-Score maupun CAMEL maka kelangsungan hidup dan pertumbuhan juga akan terjamin sehingga harapan investor untuk mendapatkan keuntungan dari pembelian saham dapat terpenuhi. 


\section{PEMBAHASAN}

\section{Analisa}

\section{a. Analisa Altman Z-Score}

Analisis dalam penelitian ini menggunakan metode Altman Z-Score untuk mengetahui bagaimana tingkat financial distress yang dialami oleh Perusahaan Sektor Aneka Industri yang tercatat di Bursa Efek Indonesia. Persamaan dari model original Altman Z-Score yaitu :

$Z=1,2 X_{1}+1,4 X_{2}+3,3 X_{3}+0,6 X_{4}+0,999 X_{5}$

Keterangan :

Z : Z Z-Score (bankruptcy index)

$\mathrm{X}_{1}$ : working capital/total asset

$\mathrm{X}_{2}$ : retained earning /total asset

$\mathrm{X}_{3}$ : earning before interest and tax/total asset

$\mathrm{X}_{4}:$ market value of equity/book value of total debt

$\mathrm{X}_{5} \quad$ : sales/total asset

Sebelum mencari nilai $\mathrm{Z}$ terlebih dahulu harus dicari nilai $\mathrm{X}_{1}, \mathrm{X}_{2}, \ldots, \mathrm{X}_{5}$. Setelah nilai masingmasing $X$ diketahui maka dapat diketahui berapa besar nilai Z. Sebagai contoh untuk mencari nilai Z perusahaan Polychem tahun 2009 memerlukan beberapa langkah yang harus dilakukan sebelum mendapatkan nilai $Z$ yaitu antara lain :

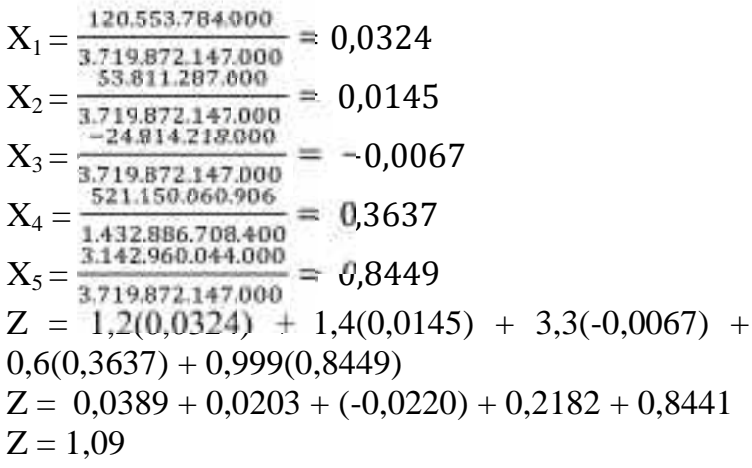

Sesuai dengan klasifikasi persamaan Altman $Z$-Score di atas nilai 1,09 $<1,8$ maka Polychem Indonesia Tbk termasuk perusahaan yang mengalami financial distress.

Dengan menggunakan cara yang sama dan berdasarkan langkah-langkah seperti contoh di atas maka dapat dihasilkan nilai $\mathrm{Z}$ pada masing-masing sampel penelitian. Untuk memudahkan pengolahan data dalam mencari nilai $\mathrm{Z}$, pada penelitian ini digunakan bantuan microsoft excel dengan berdasarkan data-data pendukung yang terdapat $\mathrm{di}$ lampiran maka diperoleh nilai $\mathrm{Z}$ pada masing-masing sampel penelitian seperti terlihat pada tabel di bawah ini :

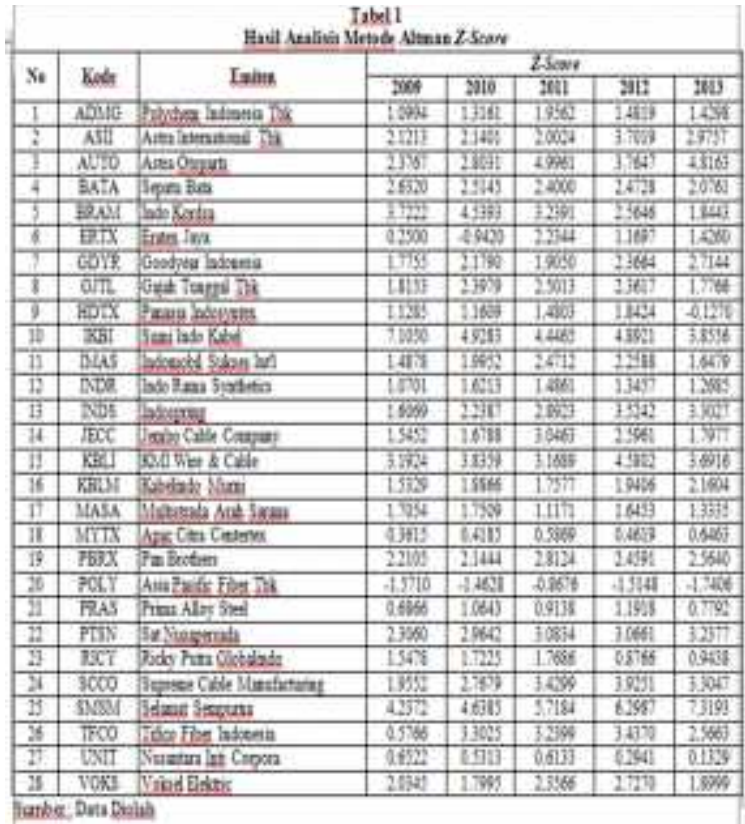

\section{b. Deskriptif Kualitatif}

\section{1) Financial Distress}

Ada beberapa emiten yang selama tahun penelitian mengalami kondisi financial distress tetapi ada juga beberapa emiten yang pada awal tahun penelitian mengalami kondisi financial distress namun di tahun berikutnya kondisi keuangannya membaik sehingga dikategorikan tidak mengalami financial distress meskipun di tahun berikutnya kembali emiten tersebut mengalami financial distress. Meskipun begitu masih ada emiten yang pada tahun awal penelitian hanya mengalami kondisi keuangan pada posisi grey area dan di tahun berikutnya membaik, sama sekali tidak mengalami financial distress hingga pada tahun terakhir penelitian.

Berdasarkan hasil penelitian, dapat dilihat bahwa nilai $\mathrm{Z}$ pada masing-masing emiten setiap tahunnya bervariasi. Polychem Indonesia Tbk mengalami kondisi financial distress pada tahun 2009 dan 2010 tetapi pada tahun 2011 kondisi keuangan emiten ini berada pada posisi grey area, namun pada tahun selanjutnya yaitu tahun 2012 dan tahun 2013 kondisi keuangan Polychem Indonesia kembali memburuk sehingga kembali berada pada kondisi financial distress. Kondisi yang sama juga dialami oleh emiten Eratex Jaya. Pada tahun 2009 sampai tahun 2011 kondisi keuangan Astra International Tbk berada pada posisi grey area. Pada tahun 2012 kondisi tersebut membaik hingga emiten tersebut berada pada posisi tidak bangkrut namun kondisis tersebut tidak dapat dipertahankan hingga di tahun 2013 Astra International mengalami financial distress, kondisi keuangan yang sama juga dialami oleh emiten Gajah Tunggal Tbk. Sedangkan keuangan emiten Astra Otoparts berada pada posisi grey area di tahun 2009 dan 2010, namun pada tahun-tahun berikutnya hingga akhir tahun penelitian kondisi keuangan emiten ini semakin membaik yaitu berada pada kondisi tidak bangkrut. Hal tersebut juga dialami oleh emiten Sat Nusapersada dan Supreme Cable Manufacturing. 


\section{2) Return Saham}

Return saham adalah pengembalian saham yang dibedakan menjadi pengembalian ekspektasi dan pengembalian realisasi yang diketahui dengan melihat perubahan nilai antara periode $t+1$ dengan periode $\mathrm{t}$ ditambah pendapat-pendapat lain yang terjadi selama periode tersebut. Atau dengan mengurangkan harga saham periode sekarang terhadap periode sebelumnya lalu dibandingkan terhadap harga saham periode sebelumnya.

Berdasarkan hasil penelitian terhadap harga saham emiten di sektor aneka industri maka diketahui return saham dari masing-masing emiten, Polychem Indonesia Tbk sebagai emiten pertama yang menjadi sampel penelitian memiliki return saham yang positif selama tahun 2009 sampai tahun 2011, namun kondisi tersebut menurun pada tahun berikutnya hingga mencapai $-0,39$ pada tahun 2013 .

Astra International Tbk memiliki tingkat pengembalian saham yang baik di awal tahun penelitian, namun kondisi tersebut semakin menurun setiap tahunnya. Pada tahun 2013 tingkat pengembalian saham emiten ini mencapai kondisi terburuk yaitu mencapai angka ekstrim -0,1053. Kondisi berbeda yang dialami Astra Otoparts dan Selamat Sempurna, meskipun selama tahun penelitian tingkat return saham tidak selalu meningkat namun angka yang dicapai masih bernilai positif berarti selama tahun 2008 sampai dengan tahun 2013 harga saham kedua emiten tersebut selalu mengalami peningkatan.

\section{c. Deskriptif Kuantitatif}

\section{1) Analisa Regresi Linier Sederhana}

Dari hasil pengolahan data, dapat dilihat nilai konstanta (a) sebesar 0,124 dan nilai koefisien regresi (b) sebesar 0,109. Maka disimpulkan model persamaan regresi : ArtanRt $=\mathbf{0 , 1 2 4}+\mathbf{0 , 1 0 9}$ $\operatorname{ArtanFd}+\varepsilon$

Persamaan regresi di atas dapat diartikan bahwa terdapat pengaruh positif antara financial distress (Altman Z-Score) terhadap return saham Perusahaan Sektor Aneka Industri yang terdaftar di Bursa Efek Indonesia.

\section{2) Analisa Korelasi dan Determinasi}

Berdasarkan hasil pengolahan data SPSS diperoleh nilai koefisien korelasi adalah sebesar 0,111 . Berdasarkan kriteria koefisien korelasi dapat disimpulkan bahwa terdapat korelasi atau hubungan antara financial distress (Altman Z-Score) terhadap return saham pada Perusahaan Sektor Aneka Industrì yang terdaftar di Bursa Efek Indonesia adalah sangat lemah.

Untuk nilai koefisien determinasi adalah sebesar 0,012 yang memiliki arti bahwa return saham dapat dijelaskan oleh financial distress (Altman Z-Score) sebesar 1,2\%, sisanya sebesar 98,8\% dijelaskan oleh variabel lain yang tidak termasuk dalam model penelitian seperti tingkat inflasi, perubahan produksi industri, tingkat pertumbuhan GNP, tingkat bunga dan tingkat penjualan.

\section{3) Uji Hipotesis (Uji t)}

Adapun hipotesis sementara yang akan diuji sebagaimana telah ditentukan sebelumnya adalah sebagai berikut :

a) $\mathrm{H}_{0}: \beta=0$ berarti financial distress (Altman $Z$ Score) berpengaruh positif dan tidak signifikan terhadap return saham pada Perusahaan Sektor Aneka Industri yang terdaftar di Bursa Efek Indonesia.

b) $\mathrm{Ha}: \beta \neq 0$ berarti berarti financial distress (Altman Z-Score) berpengaruh positif dan signifikan terhadap return saham pada

Perusahaan Sektor Aneka Industri yang terdaftar di Bursa Efek Indonesia.

Hipotesis yang digunakan untuk menguji signifikansi koefisien persamaan regresi dirumuskan sebagai berikut :

a) Jika $t_{\text {hitung }}>t_{\text {tabel }}$ atau signifikansi $<\alpha 5 \%$, maka $\mathrm{H}_{0}$ ditolak

b) Jika $t_{\text {hitung }}<\mathrm{t}_{\text {tabel }}$ atau signifikansi $>\alpha 5 \%$, maka $\mathrm{H}_{0}$ diterima

Dengan tingkat kepercayaan $95 \%$ dan $\mathrm{df}=\mathrm{n}$ $\mathrm{k}$ dimana $\mathrm{n}=140$, maka $\mathrm{df}=138$, diperoleh angka $\mathrm{t}_{\text {tabel }}$ sebesar 1,97730 sedangkan untuk $\mathrm{t}_{\text {hitung }}$ adalah sebesar 1,310. Dengan demikian maka dapat disimpulkan bahwa $\mathrm{t}_{\text {hitung }}<\mathrm{t}_{\text {tabel }}$ atau $1,310<1,97730$ maka $\mathrm{H}_{0}$ diterima. Sedangkan berdasarkan tingkat signifikansi yang diperoleh dari hasil pengolahan data SPSS menunjukkan bahwa tingkat signifikan > alpha atau 0,193 >0,05 maka dapat disimpulkan bahwa hipotesis $\mathrm{H}_{0}$ diterima.

Maka berdasarkan rangkuman hasil penelitian tersebut dapat ditarik sebuah kesimpulan yang sesuai dengan hipotesi pada penelitian ini bahwa financial distress (Altman Z-Score) berpengaruh positif dan tidak signifikan terhadap return saham pada Perusahaan Sektor Aneka Industri yang terdaftar di Bursa Efek Indonesia.

\section{Evaluasi}

a. Financial Distress (Altman Z-Score) Pada Perusahaan Sektor Aneka Industri yang Terdaftar di Bursa Efek Indonesia

Berdasarkan hasil analisis diketahui bahwa rata-rata nilai Altman Z-Score pada Perusahaan Sektor Aneka Industri yang terdaftar di Bursa Efek Indonesia sebesar 2,165935. Hal ini menunjukkan bahwa Perusahaan Sektor Aneka Industri yang terdaftar di Bursa Efek Indonesia rata-rata berada dalam kondisi grey area. Nilai minimum financial distress adalah -1.7406 dan nilai maksimum adalah 7,3193. Nilai minimum financial distress tersebut terdapat pada emiten Asia Pasific Fiber Tbk pada tahun 2013 sedangkan nilai maksimum financial distress terdapat pada emiten Selamat Sempurna di tahun 2013.

b. Return Saham Pada Perusahaan Sektor Aneka Industri yang Terdaftar di Bursa Efek Indonesia

Berdasarkan hasil penelitian dapat dilihat rata-rata return saham yang dicapai oleh perusahaanperusahaan Sektor Aneka Industri yang terdaftar di 
Bursa Efek Indonesia selama periode 2009 sampai dengan periode 2013 sebesar 0,511027. Angka tersebut menunjukkan bahwa rata-rata Perusahaan Sektor Aneka Industri yang terdaftar di Bursa Efek Indonesia mengalami return saham positif. Nilai minimum return saham adalah $-0,6818$ dan nilai maksimumnya adalah 10,8095. Nilai minimum tersebut terdapat pada emiten Sat Nusapersada pada periode tahun 2009 sedangkan nilai maksimumnya terdapat pada emiten Pan Brothers pada periode tahun 2010.

\section{c. Financial Distress (Altman Z-Score) Terhadap Return Saham Pada Perusahaan Sektor Aneka Industri yang Terdaftar di Bursa Efek Indonesia}

Dengan menggunakan analisis regresi linier sederhana diketahui bahwa financial distress (Altman Z-Score) berpengaruh positif terhadap return saham pada Perusahaan Sektor Aneka industri yang terdaftar di bursa efek indonesia. Model persamaan regresi linier sederhana yaitu ArtanRt = $\mathbf{0 , 1 2 4}+\mathbf{0 , 1 0 9} \operatorname{ArtanFd}+\boldsymbol{\varepsilon}$. Persamaan tersebut memiliki arti bahwa setiap kenaikan 1 financial distress (Altman Z-Score) akan diikuti kenaikan return saham sebesar 0,109 dan sebaliknya setiap penurunan 1 financial distress (Altman Z-Score) akan diikuti penurunan return saham sebesar 0,109. Angka 0,109 menyatakan bahwa pengaruh financial distress (Altman Z-Score) terhadap return saham adalah positif.

Berdasarkan hasil uji $\mathrm{t}$ diperoleh bahwa $\mathrm{t}_{\text {hitung }}$ $<\mathrm{t}_{\text {tabel }}$ atau 1,310 < 1,97730 maka $\mathrm{H}_{0}$ diterima dan tingkat signifikansi yang diperoleh $0,193>0,05$ maka disimpulkan bahwa $\mathrm{H}_{0}$ diterima. Hal ini menunjukkan bahwa financial distress (Altman ZScore) berpengaruh tidak signifikan terhadap return saham. Sedangkan dari hasil uji korelasi diketahui bahwa nilai $\mathrm{R}$ sebesar 0,111, maka dapat disimpulkan bahwa korelasi atau hubungan antara financial distress (Altman Z-Score) terhadap return saham sangat lemah. Hasil uji determinasi bahwa nilai $\mathrm{R}$ Square sebesar 0,012 yang memiliki arti bahwa return saham dapat dijelaskan oleh financial distress (Altman Z-Score) sebesar 1,2\%, sisanya sebesar $98,8 \%$ dijelaskan oleh variabel lain yang tidak termasuk dalam model penelitian seperti tingkat inflasi, perubahan produksi industri, tingkat pertumbuhan GNP, tingkat bunga dan tingkat penjualan.

Berdasarkan hasil analisis regresi linier sederhana, uji $\mathrm{t}$ serta pengujian korelasi dan determinasi yang telah dilakukan maka dapat disimpulkan bahwa financial distress (Altman ZScore) berpengaruh positif dan tidak signifikan terhadap return saham pada Perusahaan Sektor Aneka Industri yang terdaftar di Bursa Efek Indonesia.

Hasil penelitian ini bertentangan dengan hasil penelitian terdahulu yang telah dilakukan oleh Tarigan (2010) yang menyimpulkan bahwa tidak terdapat pengaruh nilai $z$-score terhadap harga saham. Hasil penelitian ini lebih mendekati pada penelitian terdahulu yang dilakukan oleh Naniati (2013) menyimpulkan bahwa financial distress berpengaruh tidak signifikan terhadap return saham, penelitian yang dilakukan oleh Ferdian (2011) menyimpulkan bahwa terdapat pengaruh antara kondisi financial distress perusahaan terhadap harga saham.

Begitu juga dengan penelitian yang dilakukan oleh Fakhrurozie (2007) yang menyimpulkan bahwa nilai $z$-score berpengaruh positif terhadap harga saham dan Astuti (2003) yang menyimpulkan bahwa rasio-rasio keuangan model Altman memiliki pengaruh positif terhadap harga saham. Hasil penelitian ini juga sejalan dengan teori yang dikemukakan oleh teori Brigham dan Joel yang menyimpulkan bahwa kebangkrutan yang ditandai dengan gejala kesulitan keuangan dapat mempengaruhi citra perusahaan. Apabila citra perusahaan memburuk maka dapat menyebabkan menurunnya harga saham di bursa sehingga berdampak pada tingkat pengembalian saham perusahaan.

\section{KESIMPULAN DAN SARAN}

\section{Kesimpulan}

a. Rata-rata nilai financial distress (Altman ZScore) yang dihasilkan oleh Perusahaan Sektor Aneka Industri yang terdaftar di Bursa Efek Indonesia sebesar 2,165935.

b. Rata-rata return saham pada Perusahaan Sektor Aneka Industri yang terdaftar di Bursa Efek Indonesia sebesar 0,511027. Angka tersebut menunjukkan bahwa rata-rata

c. Berdasarkan hasil analisis regresi linier sederhana yaitu ArtanRt $=0,124+0,109$ ArtanFd $+\varepsilon$, diketahui bahwa financial distress (Altman $Z$ Score) berpengaruh positif terhadap return saham. Sementara dari uji hipotesis diperoleh bahwa $t_{\text {hitung }}<t_{\text {tabel }}$ atau 1,310 $<1,97730$ dan tingkat signifikansi yang diperoleh $0,193>0,05$ maka diketahui bahwa financial distress (Altman Z-Score) berpengaruh tidak signifikan terhadap return saham.

\section{Saran}

a. Bagi perusahaan yang diteliti, disarankan untuk memberikan perhatian khusus dalam pengelolaan asset agar arus modal kerja yang dihasilkan tidak bernilai negatif.

b. Bagi BAPEPAM dan Bursa Efek Indonesia agar memperhatikan kondisi perusahaan-perusahaan yang terdaftar di Bursa Efek Indonesia, karena ada beberapa perusahaan yang mengalami kondisi keuangan yang buruk namun harga saham perusahaan tetap dalam skala yang cukup baik.

c. Bagi investor diharapkan sebelum menanamkan investasi pada Perusahaan Sektor Aneka Industri yang terdaftar di Bursa Efek Indonesia sebaiknya memperhatikan perusahaan yang memiliki nilai Z-Score di atas 2,99 dan memiliki trend positif, yaitu menunjukkan kenaikan dari tahun ke tahun. 
d. Bagi penelitian selanjutnya diharapkan menggunakan model prediksi kebangkrutan lainnya seperti Springate (1978), ZMIJEWSKI (1983) dan Grover yang diciptakan melalui penilaian dan pendesainan ulang terhadap model Altman untuk dapat dijadikan sebagai acuan dalam membandingkan prediksi kebangkrutan perusahaan.

\section{E. DAFTAR PUSTAKA}

Atmaja, Lukas Setia, 2003, Manajemen Keuangan, Edisi Revisi, Yogyakarta : Andi Offset.

Baridwan, Zaki, 2004, Intermediate Accounting, Edisi Kedelapan, Cetakan Pertama, Yogyakarta : BPFE UGM.

Brigham, Eugene F dan Joel F. Houston, 2006, Edisi Kesepuluh Dasar-Dasar Manajemen Keuangan Fundamentals of Financial Management, Jakarta: Salemba Empat.

-, 2012, Dasar-Dasar Manajemen Keuangan Essentials Of Financial Management, Jakarta: Salemba Empat.

Fakhrurozie, 2007, Analisis Pengaruh Kebangkrutan Bank Dengan Metode Altman Z-Score Terhadap Harga Saham Perusahaan Perbankan Di Bursa Efek Jakarta, Semarang : Universitas Negeri Semarang, Skripsi.

Halim, Abdul, 2007, Manajemen Keuangan Bisnis, Bogor: Ghalia Indonesia

Hartono, Jogiyanto, 2013, Teori Portofolio Dan Analisis Investasi, Edisi Kedelapan, Cetakan Pertama, Yogyakarta : BPFE.

Lubis, Ade Fatma, 2008, Pasar Modal, Jakarta : Lembaga Penerbit Fakultas Ekonomi UI.

Martono dan D. Agus Harjito, 2002, Manajemen Keuangan, Edisi Satu, Yogyakarta : Ekonosia.

Nugroho, Mokhamad, 2012, Analisis Prediksi Financial Distress Dengan Menggunakan Model Altman Z-Score Modifikasi 1995 Pada Perusahaan Manufaktur Yang Go Public Di Indonesia, Semarang : Universitas Diponegoro, Skripsi.

Situmorang, Paulus, 2008, Pengantar Pasar Modal, Edisi Pertama, Jakarta : Mitra Wacana Media.

Syahyunan, 2004, Manajemen Keuangan-I: Perencanaan, Analisis, dan Pengendalian Keuangan, Medan: USU Pres 
